J. Clin. Chem. Clin. Biochum.

Vol. 19, 1981, pp. $925-930$

\title{
Macro Creatine Kinase BB: \\ Evidence for Specific Binding between Creatine Kinase BB and Immunoglobulin G
}

\author{
By W. Stcin, J. Bohmer, J. Krais, M. Mïller, R. Steinhart and M. Eggstcin
}

Abtcilung fïr Innere Medizin IV (Direktor Prof. Dr. M. Eggstein). Medizinische Kellnik Tïbirugen

Dedicated to Professor Dr. J. Bierich on occasion of his 60 th birthday

(Roculved December 8, 1980/Februnry 27. 1981)

Summary: In the sera of four fomalo patlents with proven IgG-linked creatinc kinase BB (macro creatine kinasc BB) wo studied the nature of the binding between creatine kinasc isocnzymes and immunoglobulin $\mathrm{G}$. Tho specificily towards the isoenzyme bound, the recombination of the complex after treatment with acid buffer, the site of the binding betweon both partners and an apparently monoclonal nature of the immunoglobulin $\mathrm{G}$ involved in the com. plex indicate that a specific antigen-antibody reaction is responsible for the existenco of macro crealline kinase BB in the sera investigated.

\section{Makro-Kreatinkinase-BB: Nachweis einer spezifischen Bindung zwischen K'reatinkinase-BB ınd Immunghlobulin G}

Zusammenfassung: In den Seren von vier Patientimnen mil nachgewiesoner IgG gobundencr Kreatinkinase-BB (Makro. Kreatinkinase-BB) untersuchten wir dio Bindung zwischen den Kreatinkinitse-Isocnzymen und Immunglobulin C. Diese enzymbindenden Immunglobuline sind durch ihre Spezifitlit charaklorisiert und zeichnen sich durch ihre Ro. kombinationsfahigkeit zu Makro-Kreatinkinase aus. Dic Lokalisation der Bindung auf don Fab.Fragmenlen und dic offensichtlich monoclonale Horkunft der bindonden Immunglobuline machen cinc Antigen-Antikörper-Reaktion als Ursache dieser Makro-Krontinkinase-BB wahrschicinlich.

\section{Introduction}

Using exclusion chromatography, macro craatinc kinase $(1,2)$ (Creatine kinase, ATP: creatine-phosphotransferaso. EC 2.7.3.2) was found in the sera of patients wich an unusually high residual croatine kinase activity following immunological inhibition (3) of creatine kinase $\mathrm{M}^{\mathbf{l}}$ ) subunits. More detailed investigations showed tho prosonce of at least two difforent typos of macro creatine kinascs (4). In our casos of micro creatine kinasaemia typo 1 wo havo been able to classify the macro crontinc kinaso as a complex betwoen immunoglobulin $G$ and the isoenzymo creatine kinase $B B(5)$. Up to now it has romained obscure whether those comploxes of immuno. globulin with enzymo represent spocific antigen-antibody complexes or non-immunological complexes. In this paper we present proof of an obvious specific immunological roaction betweon crestine kinase $B B$ and the serum antibodies.

1) Abbrevlintlons: orontlino kinaso BB, croaltino klnass $M 13$, creatine kinuse MM: bruin type, houst type, strialod muscle typo eroatino kinaso isounay mes; IgC: iminunoglobulin C; $F\left(a b^{\prime}\right)_{2}$, Fab: untlbody binding fraginonts of imminostobullu G; Fc: crystallisable tragmont of IgG; Tris: tris(liydroxymothyl)methylumine; DFA E: diothylumlnouthyl.

\section{Material and Procedures}

\section{Enzyme assay}

Crontino kinaso activily was inousured at $25^{\circ} \mathrm{C}$ or, if hlgher sensilivily was necessiury, $1137^{\circ} \mathrm{C}$ will un N-llcelyleysteine renclivntud mothod (6) (CK-NAC: Bochringor, Mnnnlieim, FRG. No: 126357 or E. Murck. Durmstudi, FRG, No: 14109. 141.10 and 14111 ). The activily of our isocnzyme preparations ivas assayed with a photomiter Eppendori (M | | 01 ). The postcolumn creatine kinase nclivities of the chromutogruphic runs wore determined with an $A C P \$ 040$ minlyzer (lippondort Cicrilebuh, Hamburg. PRC). Aiter ulectrophoresis the nellvity of the crentine kinnse lsoenzymos was visuallyod as described elscewhere (5) und semunud (1.jpositripl, Hirsclimunn, Unterlasching, [PRG. Filler: $13 G 18,510 \mathrm{~nm}$ ).

\section{Isoenzy'me purification}

Iunun skclotial nuuscle, heart muscle mal uterus, obtaincil "I autopsy or surgery ware used us tissuc sources of creatine kinasc MM, MB and BB. All tissues ivere homogenlyod in Tris buffer (I minol/l, pH 8.0). The extritets were clarified by centrifuglllon (Sorvall RC 2, Dul'ont, Wilmington, USA) at A " $^{\mathrm{C}}$ and $30000 \mathrm{~g}$ lior 20 minutos and tho resiulting superniltes (I) $\mathrm{ml}$ ) wore upplicd to $1022 \times 0.9$ cin colunin of DEAl:-Sepliurose C.L-613 ecjullibratod with the homogenizing bulfur. The lsosenzymes were elutod by i linenr gradient: "wenk bulfer": I mmol/l Tris. pll 8.0. "strong buflfur": 50 minol/l 'I'ris, 300 mniol/I NaCl. pll 7.0. Tlis appropriate fractlons woro poolod, cancentratol und ultruliltered witl Tris buffier ( 50 mmol/l. 50 mmol// NaCl, 20 mmol/1 N-ucetylcysteine, phl 7.0) in an Amicon concentrilur 
(membrane UM 10; Amicon, Witten, FRG). The purity of the creatine kinase isoenzymes was checked by electrophoresis on agarose gel (5).

${ }^{125}$ I labeled creatine kinase BB was purchased from DRG instruments (Marburg, FRG). Impurities were removed by ion exchange chromatography using DEAE-Sephadex A-50 columns (Roche Diagnostics, Nutley, USA).

\section{Purification of Immunoglobulin $G$}

Immunoglobulin $G(1,2,4$-subclass) from the sera (4 ml) of four patients (Doe. E., Kes. E., Rud. M., Sch. L.) with proven (according to (5)) IgG-linked creatine kinase BB, was purified by affinity chromatography on Protein A-Sepharose CL-4B $(5 \times 0.8 \mathrm{~cm})(7,8)$. IgG was eluted with an acid glycine buffer $(50 \mathrm{mmol} / \mathrm{l}, \mathrm{pH} 3.0)$. The $\mathrm{IgG}$ containing fractions were pooled, concentrated (membrane UM 10) to $4 \mathrm{ml}$ and the $\mathrm{pH}$ was adjusted to 7.0 with $\mathrm{NaOH}(1 \mathrm{~mol} / \mathrm{l})$.

\section{Recombination of macro creatine kinase in vitro}

The purified IgG solutions were incubated with creatine kinase $\mathrm{BB}$ or $\mathrm{MB}$ for $1 \mathrm{~h}$ at $4^{\circ} \mathrm{C}$ before electrophoresis, activity staining and scanning.

Cross reactivity between IgG and creatine kinase $\mathrm{BB}$ or $\mathrm{MB}$ was tested by incubating $120 \mu \mathrm{g}$ of immunoglobulin $\mathrm{G}$ and $3 \mathrm{mU}$ of creatine kinase $\mathrm{MB}$ with increasing amounts of creatine kinase BB $(0-3 \mathrm{mU})$. After incubation for $1 \mathrm{~h}$ at $4^{\circ} \mathrm{C}$ the samples were electrophoresed, stained for creatine kinase activity and photographed.

\section{Pepsin digestion}

$4 \mathrm{ml}$ of the IgG solution and $0.5 \mathrm{mg}$ pepsin (EC 3.4.23.1) (Merck, Darmstadt, FRG, No. 7192) were incubated at $37^{\circ} \mathrm{C}$ for $17 \mathrm{~h} \mathrm{(50} \mathrm{mmol} / 1$ gly cine-HCl buffer, $\mathrm{pH} 4.5)$. Digestion was stopped by cooling and adjusting the $\mathrm{pH}$ to 8.0 with $\mathrm{NaOH}$ $(1 \mathrm{~mol} / \mathrm{l})$.

\section{Papain digestion}

$4 \mathrm{ml}$ of the igG solution and $1.2 \mathrm{mg}$ of papain (EC 3.4.22.2) (Merck, Darmstadt, FRG, Nr. 7144) were incubated according to Goding (8) for $6 \mathrm{~h}$ at $37^{\circ} \mathrm{C}$ and $\mathrm{pH} 8.0$. The reaction was stopped by cooling the mixture to $0^{\circ} \mathrm{C}$.

\section{Preparation of $F\left(a b^{\prime}\right)_{2}$ fragments}

After pepsin treatment of the IgG, undigested IgG was removed by affinity chromatography on Protein A-Sepharose CL-4B (fig. 1a). The crude $F\left(a^{\prime}\right)_{2}$ fraction was further purified by exclusion chromatography on Sephadex G-100 sf $(59 \times 0.9 \mathrm{~cm})$ (fig. 1b). Fractions 39-50 were pooled and concentrated (membrane UM 10) to $0.8 \mathrm{ml}$. The molecular weight was confirmed to be in the range of 95000 (fig. 2, C), and the purity of the $F\left(a b^{\prime}\right)_{2}$ fragments was checked by antisera using the Ouchterlony technique.

\section{Preparation of Fab fragments}

After papain treatment of the IgG, undigested IgG and Fc fragments were removed by affinity chromatography on Protein A-Sepharose CL-4B. The crude Fab fraction was further purified by exclusion chromatography on Sephadex G-100 sf $(59 \times$ $0.9 \mathrm{~cm}$ ). Fractions $46-59$ were pooled and concentrated (membrane UM 10) to $0.8 \mathrm{ml}$. The purity was checked by rechromatography as described above (fig. 1c). The molecular weight was determined to be approximately 42000 (fig. 2, A).

\section{Preparation of Fc fragments}

After papain digestion of the IgG, the undigested IgG and the $\mathrm{Fc}$ fragments remained on the column during affinity chromatography on Protein A-Sepharose CL-4B. They were eluted together at pH 3.0 (gly cine-HCl buffer, $50 \mathrm{mmol} / \mathrm{l}$ ). Further purification was achieved by exclusion chromatography on Sephadex G-100 sf $(59 \times 0.9 \mathrm{~cm})$. Fractions 47-58 were pooled and concentrated to $0.8 \mathrm{ml}$ (membrane UM 10); their purity was checked
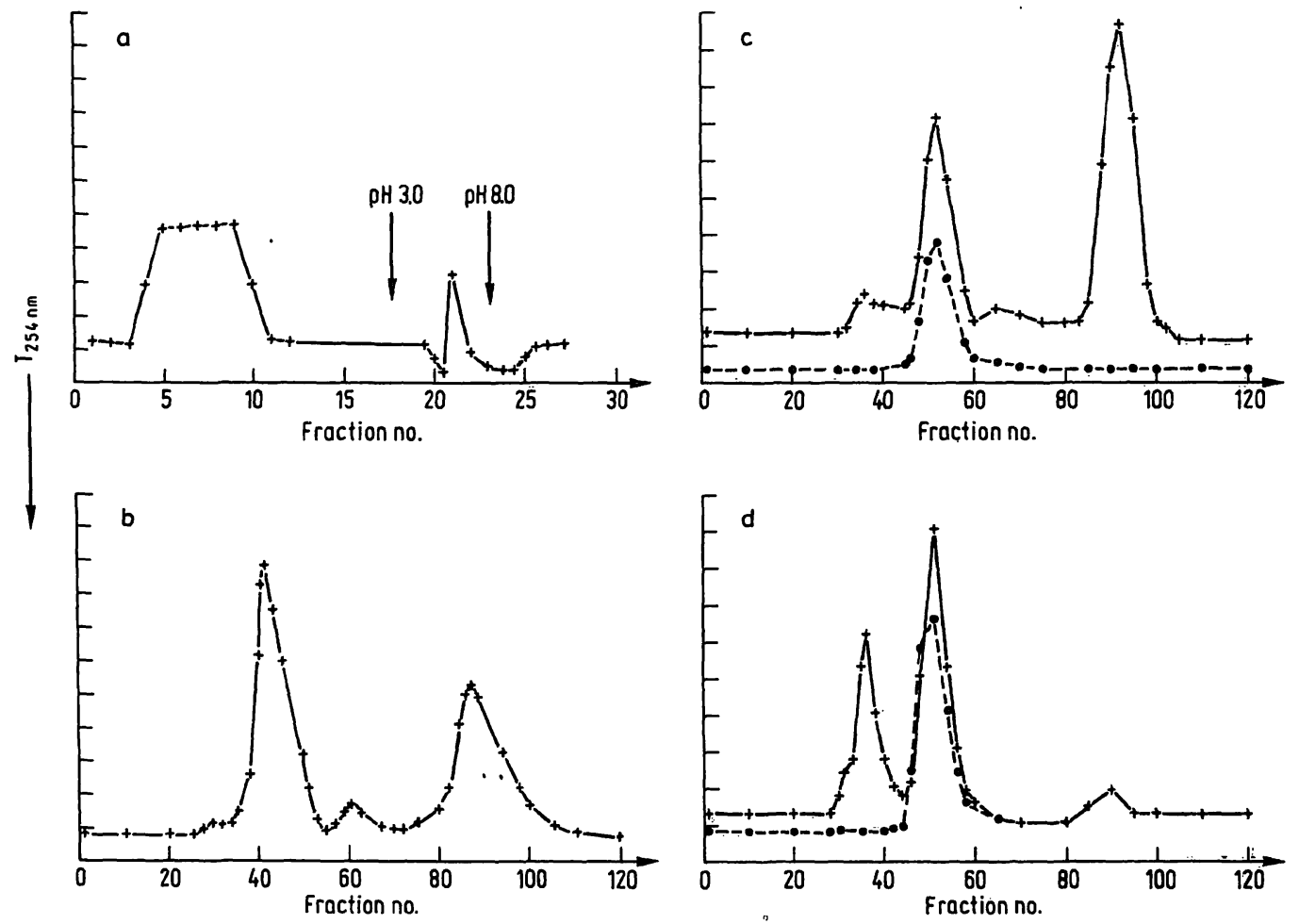

Fig. 1. Purification of IgG fragments after pepsin/papain digestion.

Fig. 1a. Affinity chromatography on Protein A-Sepharose CL-4B of the reaction mixture after pepsin digestion of IgG; $2 \mathrm{ml}$ fractions. Fractions 4-10: crude $\mathrm{F}\left(\mathrm{ab}^{\prime}\right)_{2}$ fragments. Fraction 21: undigested IgG. $y$-axis: Tránsmission at $254 \mathrm{~nm}$. Fig. 1b-1d. Exclusion chromatography on Sephadex G-100 sf $(59 \times 0.9 \mathrm{~cm})$ of $F\left(a^{\prime}\right)_{2}$ (fig. 1b), Fab (fig. 1c) and Fc (fig. 1d) fragments; $440 \mu$ l fractions.

+-+-+ : crude fragments. $-\cdots-\bullet$ : purified fragments. $y$-axis: Transmission at $254 \mathrm{~nm}$. 


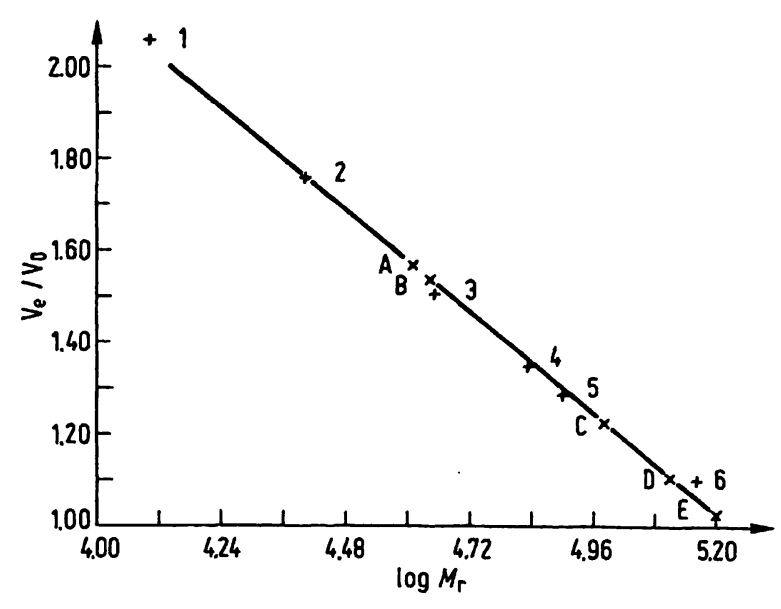

Fig. 2. Determination of molecular weights by exclusion chromatography on Sephadex G-100 sf $(59 \times 0.9 \mathrm{~cm})$.
Calibration standards $(+)$
1 Cytochrome c (12500)
2 Chymotrypsinogen A (25000)
3 Albumin from hen egg (45000)
4 Albumin from bovine serum $(68000)$
5 Creatine kinase (CK) BB (80000)
6 IgG (146000) (10).

Results (x)
A: Fab fragments
B: Fc fragments
$M_{\mathrm{r}}: 42000(41000)(9)$
C: $F\left(a^{\prime}\right)_{2}$ fragments
$M_{\mathrm{r}}: 45000(50000)(9)$
$M_{\mathrm{r}}: 95000(92000)(9)$
D: CK-Fab complex
$M_{\mathrm{r}}: 130000$ (expected: 121000 )
E: $C K-F\left(a b^{\prime}\right)_{2}$ complex $M_{\mathrm{r}}$ : at least 160000

by rechromatography (fig. 1d). The molecular size was estimated to be approximately 45000 (fig. 2, B).

\section{Determination of the binding site between creatine kinase $B$ subunits and immunoglobulin $G$ or its fragments}

$200 \mu \mathrm{l}$ of $\mathrm{IgG}$ or its fragments and $67 \mu \mathrm{l}$ of creatine kinase BB $(2100 \mathrm{U} / 1)$ or creatine kinase MB $(2000 \mathrm{U} / \mathrm{l})$ were incubated for $1 \mathrm{~h}$ at $25^{\circ} \mathrm{C}$ and $1 \mathrm{~h}$ at $4{ }^{\circ} \mathrm{C}(\mathrm{pH} \mathrm{7.0})$.

$150 \mu \mathrm{l}$ of these mixtures were chromatographed on Sephacryl S-200 sf $(55 \times 0.9 \mathrm{~cm})$ or Sephadex G-100 sf $(59 \times 0.9 \mathrm{~cm})$. Post column creatine kinase activities were determined as described. $12 \mu$ l of each mixture were applied onto agarose plates, electrophoresed and stained for creatine kinase activity. $20 \mu \mathrm{l}$ of the mixtures were used in the double diffusion method (Ouchterlony) (5). The antisera applied were purchased from Dako, Kфpenhavn, Denmark (Anti-IgG (Fc specific), Anti-kappa Anti-lambda, Añti-IgG (gamma chain)) and Behringwerke, Marburg, FRG (Anti-IgG/Fd, Anti-IgG/Fab, Anti-IgG/Fc).

$10 \mu \mathrm{l}$ of $\mathrm{IgG}$ or its fragments and $10 \mu \mathrm{l}$ of ${ }^{125}$ I-labeled creatine kinase BB were incubated at $25^{\circ} \mathrm{C}$ for $1 \mathrm{~h}$. Electrophoresis was performed as described and the plates were placed on X-ray films for autoradiography.

\section{Results}

Immunoglobulin $G$ was easily separated from the sera by affinity chromatography on Protein A-Sepharose CL-4B. As already described $(5,11)$ not only free immunoglobulin $\mathbf{G}$ but also enzyme-linked immunoglobulin $\mathrm{G}$ is quantitatively fixed by Protein $A$. Acid elution of the immunoglobulin $G$ resulted in a pure immunoglobulin $G$ fraction, which no longer showed creatine kinase activity. Immunoglobulin $\mathbf{G}$ from all four patients' sera recombined not only with autologous creatine kinase BB
(Doe. E.) (5), but also with homologous creatine kinase $\mathrm{BB}$, to form macro creatine kinase. In one case (Rud. M.), after incubation of immunoglobulin $G$ with creatine kinase $\mathrm{MB}$, macro creatine kinase $\mathrm{MB}$ was formed in amounts comparable to the formation of macro creatine kinase $\mathrm{BB}$ from creatine kinase $\mathrm{BB}$ and immunoglobulin G. The immunoglobulin molecules of this serum showed a marked cross reactivity between creatine kinase $B B$ and creatine kinase $\mathrm{MB}$, as determined by incubating constant amounts of immunoglobulin $G$ and creatine kinase $\mathrm{MB}$ with increasing amounts of creatine kinase BB. Figure 3 shows the displacement of creatine kinase $M B$ from its immunoglobulin $G$ linkage due to the addition of creatine kinase $\mathrm{BB}$. Creatine kinase $\mathrm{MM}$ never became fixed to immunoglobulin $\mathrm{G}$ in measurable amounts. Figure 4 shows densitograms after electrophoresis of the reconstituted macro creatine kinase BB and macro creatine kinase MB.

After papain digestion, the purified Fab fragments revealed a high affinity to creatine kinase $B B$, which resulted in the formation of complexes between $\mathrm{Fab}$ and creatine kinase BB. One example (Rud. M.) is given in figure 5a. The shift of the molecular weight of the creatine kinase activity to higher values due to complexation with Fab fragments is clearly documented by exclusion chromatography. From these data we concluded that complexes with a 1:1 molar ratio between the Fab fragments and creatine kinase BB are formed. The molecular mass of these complexes was 130000 (fig. 2, D). The formation of atypically migrating creatine kinase activity bands during electrophoresis of the Fab-creatine kinase BB mixture also indicated stable complex formation (fig. 4).

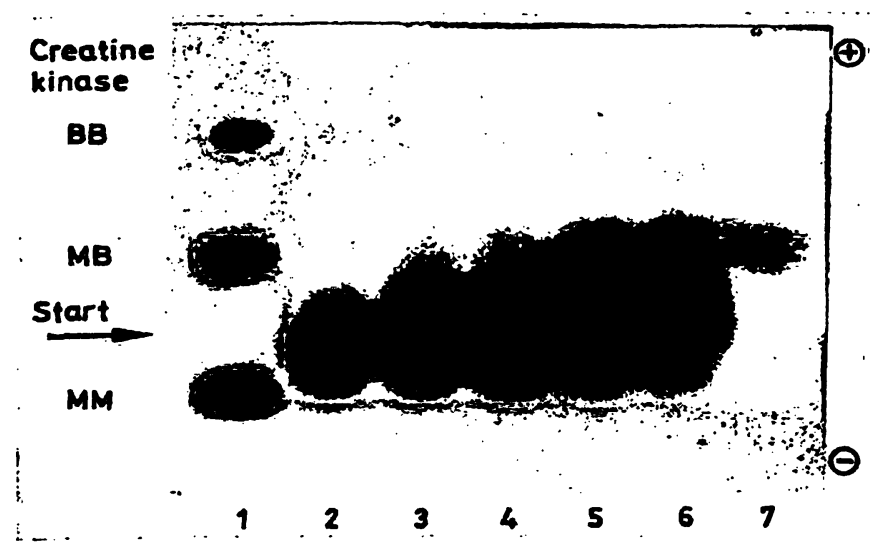

Fig. 3. Macro creatine kinase MB: displacement of bound creatine kinase $\mathrm{MB}$ by increasing amounts of creatine kinase BB. Electrophoresis on agarose gel; activity staining.

$\rightarrow$ : electrophoretic origin. Anode at the top.

1: standard, 2-6: macro creatine kinase MB (3 mU creatine kinase $\mathrm{MB}$ ) incubated with increasing amounts of creatine kinase $\mathrm{BB}(0,0.6,1.2,2.4,3.0 \mathrm{mU})$. 7: creatine kinase $\mathbf{M B}$. 


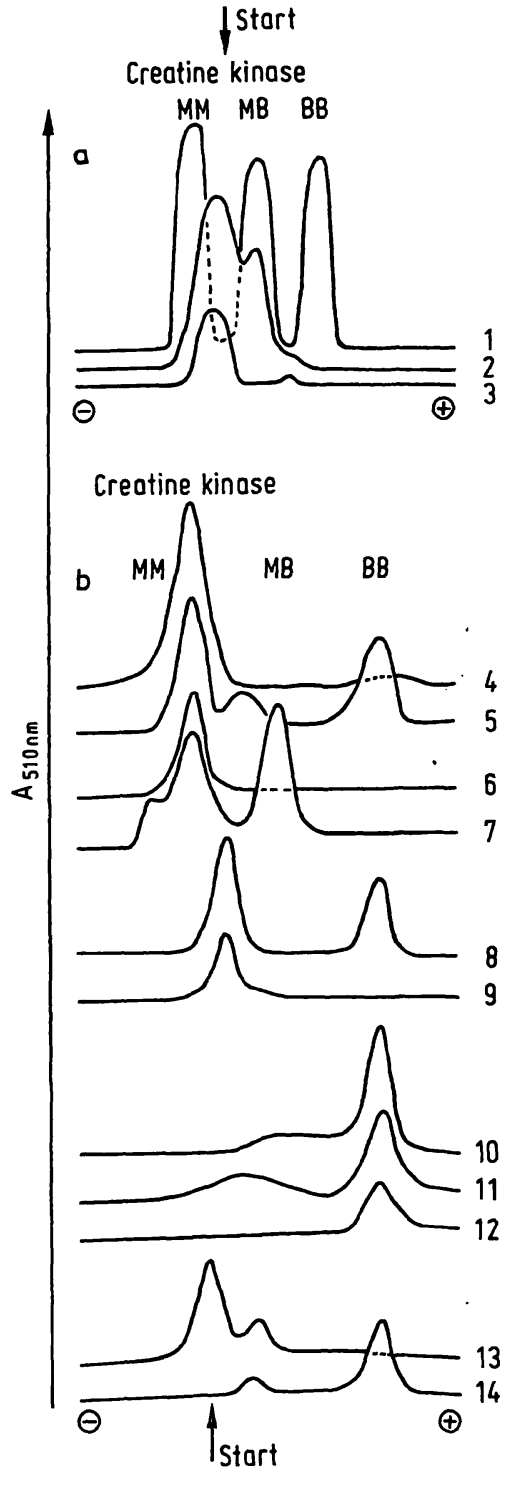

Fig. 4. Agarose gel electrophoresis, scanned at $510 \mathrm{~nm}$. $\rightarrow$ : electrophoretic origin

Stained for enzy me activity: lanes $1-3,6,7,12$ Autoradiograms: lanes 4, 5, 8-11, 13, 14 $\mathrm{y}$-axis: Absorbance at $510 \mathrm{~nm}$.

Fig. 4a.

1: standard: creatine kinase $M M$, creatine kinase $M B$, creatine kinase $\mathrm{BB}$ (left to right)

2: macro creatine kinase MB, recombined (IgG Rud. M. and creatine kinase $\mathrm{MB}$ )

3: macro creatine kinase BB, recombined (IgG Rud. M. and creatine kinase $\mathrm{BB}$ )

Fig. 4b.

4: $\mathrm{F}\left(\mathrm{ab}^{\prime}\right)_{2}{ }^{-125}$ I-CK-BB (Kes. E.)

5: $\mathrm{F}\left(\mathrm{ab}^{\prime}\right)_{2}{ }^{125} \mathrm{I}-\mathrm{CK}-\mathrm{BB}$ (Doe. E.)

6: $\mathrm{F}\left(\mathrm{ab}^{\prime}\right)_{2}-\mathrm{CK}-\mathrm{BB}$ (Rud. M.)

7: $F\left(a^{\prime}\right)_{2}$-CK-MB (Rud. M.)

8: Fab- ${ }^{125} \mathrm{I}-\mathrm{CK}-\mathrm{BB} \quad$ (Kes. E.)

9: Fab-125I-CK-BB (Rud. M.)

10: $\mathrm{FC}^{-125} \mathrm{I}-\mathrm{CK}-\mathrm{BB}$ (Doe. E.)

11: $\mathrm{Fc}^{125} \mathrm{I}-\mathrm{CK}-\mathrm{BB} \quad$ (Kes. E.)

12: FC-CK-BB (Rud. M.)

13: ${ }^{125} \mathrm{I}$-macro creatine kinase $\mathrm{BB}$

14: ${ }^{125} \mathrm{I}-\mathrm{CK}-\mathrm{BB}$

Under the same conditions no similar high level of complex formation was detectable after incubation of purified $\mathrm{Fc}$ fragments and creatine kinase BB (fig. $4,5 \mathrm{~b}$ ).
After pepsin digestion the purified $F\left(a b^{\prime}\right)_{2}$ fragments showed a high affinity to creatine kinase $\mathrm{BB}$, which resulted in the formation of complexes. Two examples (Kes. E., Doe. E.) are given in figure $5 \mathrm{a}$ and $5 \mathrm{c}$. The shift of the molecular weight of the creatine kinase activity to higher values due to complexing with the $\mathrm{F}\left(\mathrm{ab}^{\prime}\right)_{2}$ fragments is clearly demonstrated by exclusion chromatography. From these data we concluded that complexes with a $1: 1$ or $2: 1$ molar ratio between creatine kinase $B B$ and the $F\left(a b^{\prime}\right)_{2}$ fragments are formed. The molecular mass of the $\mathrm{F}\left(\mathrm{ab}^{\prime}\right)_{2}$-creatine kinase $\mathrm{BB}$ complexes was at least 160000 (fig. 2,E): a value which already almost equals the void volume of our G-100 sf column. Furthermore, the formation of atypically migrating creatine kinase activity bands after electrophoresis, due to complexing of enzyme with the $\mathrm{F}\left(\mathrm{ab}^{\prime}\right)_{2}$ fragments, is documented in figure 4.

In the sera of two patients (Rud. M., Kes. E.) we determined the light chains of the creatine kinase $\mathrm{BB}$ and MB-binding immunoglobulins. Figure 6 shows our results on the $F\left(a b^{\prime}\right)_{2}$ fragments of serum Rud. M. after double diffusion (Ouchterlony) and staining for creatine kinase activity. The two main precipitin lines indicated binding between creatine kinase BB or (but to a lesser degree) creatine kinase $\mathrm{MB}$ and kappa-type light chains in the $F\left(a b^{\prime}\right)_{2}$ region of the immunoglobulin $G$ molecule. In addition, the faint precipitin lines between anti-Fd serum and the $F\left(a b^{\prime}\right)_{2}$-linked creatine kinase isoenzymes and the absence of precipitin lines with anti-Fc serum demonstrated pure $F\left(a b^{\prime}\right)_{2}$ fragments.

In serum Kes.E. the creatine kinase-binding immunoglobulin $\mathrm{G}$ light chains proved to belong to the lambda subclass.

A summary of our results is given in table 1 .

\section{Discussion}

Immunoglobulin G-linked creatine kinase BB isoenzyme has been reported in the sera of patients with several diseases. Up to now it has remained unclear whether this is a specific antigen-antibody reaction or a nonspecific protein-immunoglobulin complex $(1,2,12)$. Here we show the existence of an antibody for creatine kinase BB. The immunoglobulin G-linked creatine kinase BB in the four sera investigated fulfilled the following criteria which are typical for specific immunological antigenantibody reactions:

1. The binding between creatine kinase $\mathrm{B} \overline{\mathrm{B}}$ and immunoglobulin $G$ is reversible: Acidolytic treatment of the macro creatine kinase complexes destroyed all creatine kinase activity. After chromatographic purification, the acid-stable immunoglobulin $\mathrm{G}$ fractions easily recombined not only with autologous but also with homologous creatine kinase BB, to form macro creatine kinase. Furthermore these results indicate that the formation of 

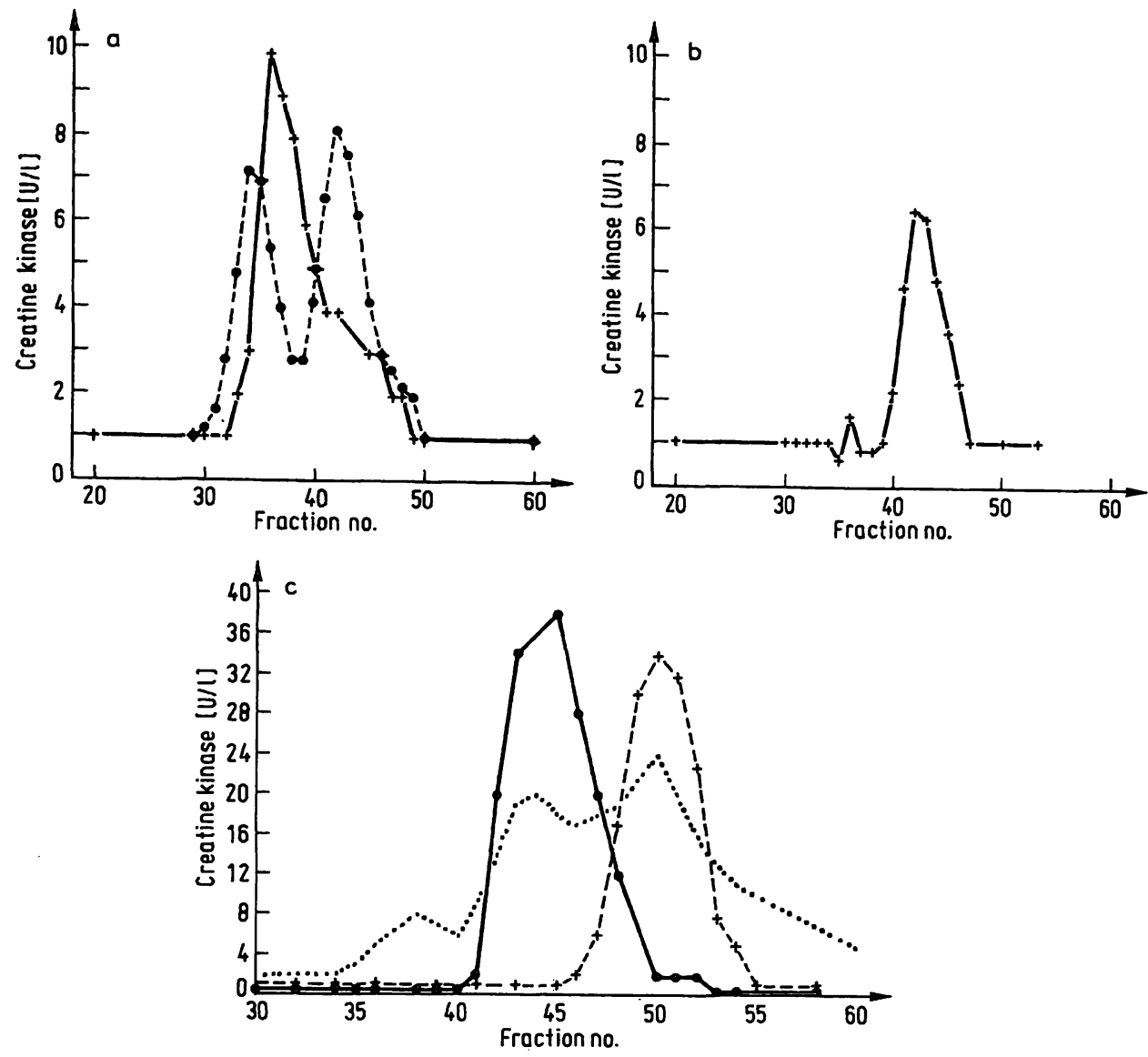

Fig. 5. Complexation of creatine kinase BB by fragments of IgG.

Fig. 5a. Exclusion chromatography on Sephadex G-100 sf $(59 \times 0.9 \mathrm{~cm}), 440 \mu l$ fractions $+++-+:$ Fab (Rud. M.) incubated with creatine kinase BB.

$\bullet-\cdots: F\left(a^{\prime}\right)_{2}$ (Kes. E.) incubated with creatine kinase BB.

First peak: $F\left(a b^{\prime}\right)_{2}-C K-B B$ complex, second peak: normal creatine kinase BB.

Fig. 5b. Same column as fig. $5 \mathrm{a}, 440 \mu \mathrm{l}$ fractions

++++ Fc (Doe. E.) incubated with creatine kinase BB.

Fig. 5c. Exclusion chromatography on Sephacryl S-200sf $(52 \times 0.9 \mathrm{~cm}), 440 \mu l$ fractions

$\ldots \ldots \ldots$ : Transmission at $254 \mathrm{~nm}$, normal serum

+- +- +): Creatine kinase BB in normal serum (creatine kinase activity)

$\bullet-\longrightarrow \mathrm{F}\left(\mathrm{ab}^{\prime}\right)_{2}$ (Doe. E.) incubated with creatine kinase BB.
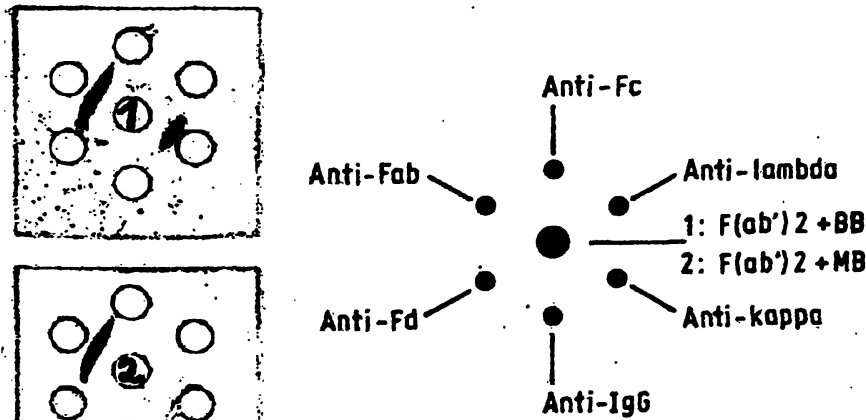

Fig. 6. Determination of the binding of creatine kinasc $B B$ and creatine kinase $\mathrm{MB}$ with $\mathrm{F}\left(\mathrm{ab}^{\prime}\right)_{2}$, and determination of the IgG light chains complexing creatine kinase BB and creatine kinase MB. Ouchterlony technique on agarose plates. Creatinc kinase activity staining.
Kes.E.

Rud.M.

Tab. 1. Complexing of creatine kinase (CK) isoenzymes by immunoglobulin $G$ or its fragments from the sera of four patients with proven macro creatine kinase BB.

\begin{tabular}{|c|c|c|c|c|c|}
\hline \multirow{3}{*}{ Patient } & \multicolumn{5}{|c|}{ Complexing with } \\
\hline & \multicolumn{2}{|l|}{ CK-BB } & \multicolumn{2}{|l|}{ CK-MB } & CK-MM \\
\hline & $\begin{array}{l}\text { IgG: } \\
\text { F(ab' }{ }_{2}: \\
\text { Fab: } \\
\text { Fc: }\end{array}$ & $\begin{array}{l}+ \\
+ \\
+ \\
\text { trace }\end{array}$ & IgG: & trace & IgG: - \\
\hline Kes.E. & $\begin{array}{l}\operatorname{IgG}(\lambda): \\
\mathrm{F}\left(\mathrm{ab}^{\prime}\right)_{2}: \\
\text { Fab: } \\
\text { Fc: }\end{array}$ & $\begin{array}{l}+ \\
+ \\
+ \\
\text { trace }\end{array}$ & IgG: & - & IgG: - \\
\hline Rud.M. & $\begin{array}{l}\operatorname{IgG}(\kappa): \\
\mathrm{F}\left(\mathrm{ab}^{\prime}\right)_{2}: \\
\text { Fab: } \\
\text { Fc: }\end{array}$ & $\begin{array}{l}+ \\
+ \\
+ \\
-\end{array}$ & $\begin{array}{l}\operatorname{IgG}(k): \\
\mathrm{F}\left(a b^{\prime}\right)_{2}:\end{array}$ & + & IgG: - \\
\hline Sch.L. & $\begin{array}{l}\text { IgG: } \\
F\left(a b^{\prime}\right)_{2}:\end{array}$ & + & IgG: & - & IgG: - \\
\hline
\end{tabular}


macro creatine kinase $\mathrm{BB}$ is due to the occurrence of specific, creatine kinase binding immunoglobulin $\mathrm{G}$ molecules and not due to alterations in the patients' creatine kinase BB.

2. The binding between creatine kinase BB and immunoglobulin $G$ is specific: Three out of four of the immunoglobulin $G$ preparations showed a high affinity to creatine kinase $\mathrm{BB}$ exclusively. Additionally, in one case, not only creatine kinase $\mathrm{BB}$ but also creatine kinase $\mathrm{MB}$ was bound to a great extent. Both isoenzymes showed a typical competition for the binding sites on the immunoglobulin $G$ molecules, in the course of which creatine kinase $\mathrm{BB}$ revealed a higher affinity to immunoglobulin $G$ than creatine kinase MB.

3. The Fc pieces of the IgG molecules involved in the macro creatine kinase complexes were still able to react with staphylococcal protein A without detaching the bound creatine kinase $\mathrm{BB}$. We therefore assume that the Fc pieces are free i. e. they are apparently not participants in the binding between creatine kinase BB and immunoglobulin $\mathrm{G}$.

4. These findings were confirmed by our results after pepsin and papain digestion of the immunoglobulin $G$. By exclusion chromatography, electrophoresis followed by activity staining or autoradiography and double diffusion, followed by double antibody fixation of the creatine kinase $\mathrm{BB}$, we were able to localize the binding between the immunoglobulin $G$ and creatine kinase $B B$ in the Fab region of the immunoglobulin G. According to the increase of the molecular weight of creatinekinase $\mathrm{BB}$, due to connection with the Fab fragments of immunoglobulin $G$, a stoichiometric ratio of $1: 1$ be- tween creatine kinase $\mathrm{BB}$ and the Fab fragments of $\mathrm{IgG}$ is highly probable.

In contrast to our results from complexing $\mathrm{Fab}$ fragments with creatine kinase isoenzymes, there was no comparable binding of creatine kinase $\mathrm{BB}$ with the $\mathrm{Fc}$ fragments of immunoglobulin G.

5. In two cases we were able to identify the subclass of the immunoglobulin $G$ light chains involved in the macro creatine kinase $\mathrm{BB}$. The monoclonal form of these light chains likewise indicated a specific immunological antigen-antibody reaction.

The objective of this study was to elucidate the nature of the binding between creatine kinase BB and immunoglobulin $G$ in the sera of four patients with proven macro creatine kinase BB. Jockers-Wretou et. al. (12) excluded the possibility of antibody formation against creatine kinase $\mathrm{BB}$, although in their reported case the macro creatine kinase proved to be composed of creatine kinase $\mathrm{BB}$ and immunoglobulin G. Their conclusions were drawn from experiments which, in our opinion, have only reduced probative force. Here we are able to show that a specific immunological reaction between creatine kinase $\mathrm{BB}$ and the Fab region of the binding immunoglobulin $\mathrm{G}$ caused the unusual behaviour of creatine kinase in these sera.

\section{Acknowledgements}

We are grateîul to Drs. Bürkle and Siguda, Tübingen for providing us with human tissues.

\section{References}

1. Urdal, P. \& Landaas, S. (1979), Clin. Chem. 25, 461-465.

2. Bohner, J., Stein, W., Kuhlmann, E. \& Eggstein, M. (1979), Clin. Chim. Acta 97, 83-88.

3. Würzburg, U., Hennrich, N., Lang, H., Prellwitz, W., Neumeier, D. \& Knedel, M. (1976), Klin. Wochenschr. 54, 357360.

4. Stein, W., Bohner, J. \& Steinhart, R. (1981), J. Clin. Chem. Clin. Biochem. in press.

5. Stein, W., Bohner, J., Eggstein, M. \& Lang, H. (1979), J. Clin. Chem. Clin. Biochem. 17, 739-745.

6. Szasz, G., Gruber, W. \& Bernt, E. (1976), Clin. Chem. 22, 650-656.
7. Goding, J. W. (1976), J. Immunol. Meth. 13, 215-226.

8. Goding, J. W. (1978), J. Immunol. Meth. 20, 241-253.

9. Utsumi, S. \& Karush, F. (1965), Biochemistry 4, 17661779.

10. Schwick, H. G. \& Haupt, H. (1980), Angew. Chem. 92, 83-95.

11. Kajita, Y., Majima, T., Yoshimura, M., Hachiya, T., Miyazaki, T., Ijichi, H. \& Ochi, Y. (1978), Clin. Chim. Acta 89, 485-489.

12. Jockers-Wretou, E. \& Plessing, E. (1979), J. Clin. Chem. Clin. Biochem. 17, 731-737.

Dr. Dr. Wolfgang Stein Dr. Jürgen Bohner Medizinische Klinik Abt. 4

D-7400 Tübingen 